
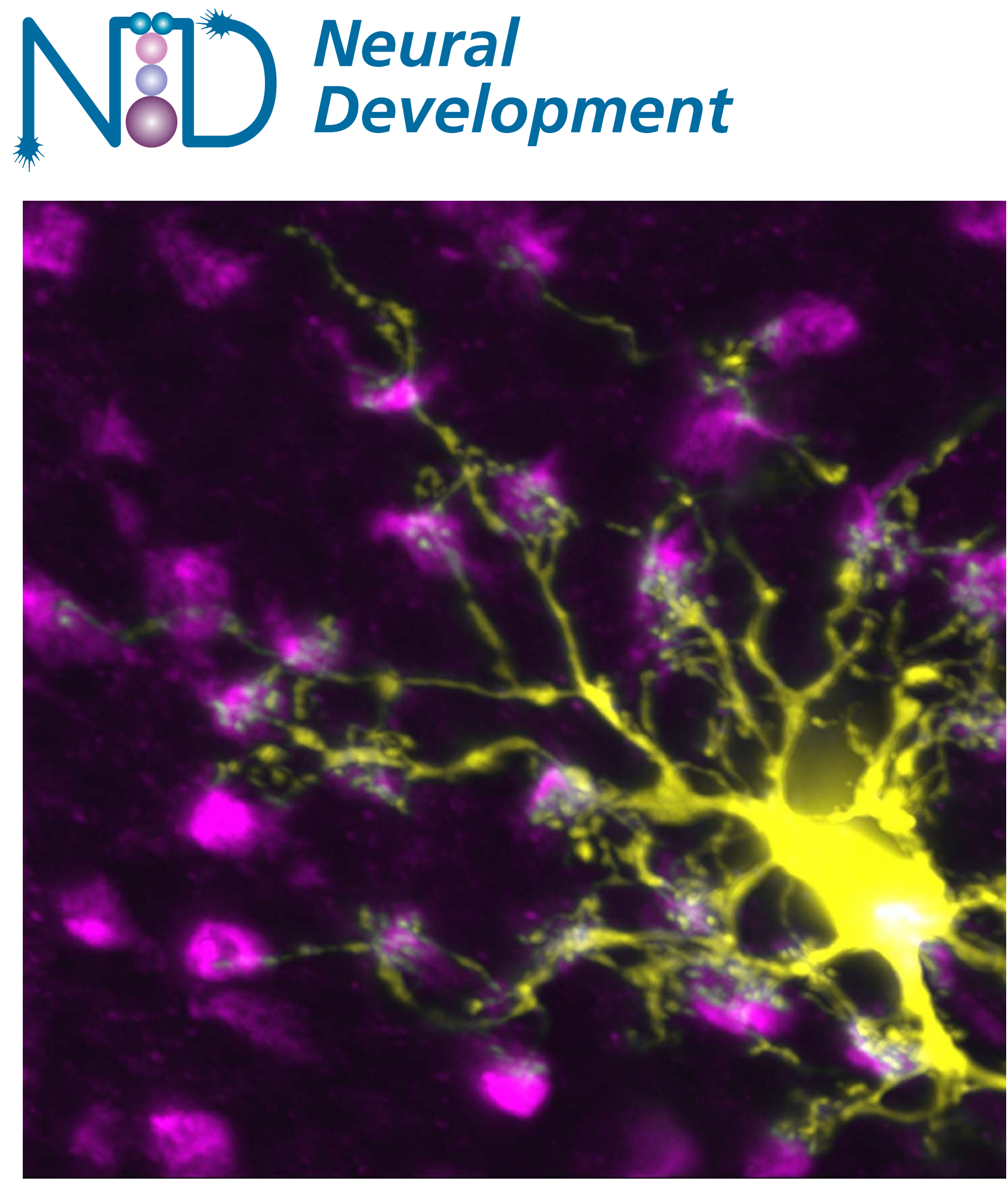

Assembly of the outer retina in the absence of GABA synthesis in horizontal cells

Schubert et al.

C Biomed Central 


\title{
Assembly of the outer retina in the absence of GABA synthesis in horizontal cells
}

Timm Schubert ${ }^{1,2 \dagger}$, Rachel M Huckfeldt ${ }^{1 \dagger}$, Edward Parker $^{3}$, John E Campbell ${ }^{1}$, Rachel OL Wong ${ }^{1 *}$

\begin{abstract}
Background: The inhibitory neurotransmitter gamma-amino-butyric acid (GABA) not only modulates excitability in the mature nervous system but also regulates neuronal differentiation and circuit development. Horizontal cells, a subset of interneurons in the outer retina, are transiently GABAergic during the period of cone photoreceptor synaptogenesis. In rodents, both horizontal cells and cone axonal terminals express $G_{A B A}$ receptors. To explore the possibility that transient GABA expression in mouse neonatal horizontal cells influences the structural development of synaptic connectivity in the outer retina, we examined a mutant in which expression of GAD67, the major synthesizing enzyme for GABA, is selectively knocked out in the retina.

Results: Immunocytochemistry and electron microscopy revealed that the assembly of triad synapses involving cone axonal pedicles and the dendrites of horizontal and bipolar cells is unaffected in the mutant retina. Moreover, loss of GABA synthesis in the outer retina did not perturb the spatial distributions and cell densities of cones and horizontal cells. However, there were some structural alterations at the cellular level: the average size of horizontal cell dendritic clusters was larger in the mutant, and there was also a small but significant increase in cone photoreceptor pedicle area. Moreover, metabotropic glutamate receptor 6 (mGluR6) receptors on the dendrites of ON bipolar cells occupied a slightly larger proportion of the cone pedicle in the mutant.

Conclusions: Together, our analysis shows that transient GABA synthesis in horizontal cells is not critical for synapse assembly and axonal and dendritic lamination in the outer retina. However, pre- and postsynaptic structures are somewhat enlarged in the absence of GABA in the developing outer retina, providing for a modest increase in potential contact area between cone photoreceptors and their targets. These findings differ from previous results in which pharmacological blockade of $G A B A_{A}$ receptors in the neonatal rabbit retina caused a reduction in cone numbers and led to a grossly disorganized outer retina.
\end{abstract}

\section{Background}

In addition to its essential role in the mature nervous system, the inhibitory neurotransmitter gamma-aminobutyric acid (GABA) has been shown to regulate many aspects of neuronal development [1,2], including cell proliferation, migration [3], morphogenesis [4], and circuit assembly and refinement $[5,6]$. Indeed, the lack of GABA synthesis in cortical interneurons decreases the number of synaptic boutons formed onto the somata of their postsynaptic targets, the pyramidal cells [5]. Some neurons, however, also receive presynaptic GABAergic input from the same postsynaptic cells they innervate

\footnotetext{
* Correspondence: wongr2@u.washington.edu

† Contributed equally

'Department of Biological Structure, University of Washington, School of Medicine, 1959 NE Pacific St, Seattle, WA 98195, USA
}

(c) 2010 Schubert et al; licensee BioMed Central Ltd. This is an Open Access article distributed under the terms of the Creative Commons Attribution License (http://creativecommons.org/licenses/by/2.0), which permits unrestricted use, distribution, and reproduction in any medium, provided the original work is properly cited.

[7]. But, as yet, it is not known whether perturbation of GABA synthesis in postsynaptic cells also affects the development of their connectivity with their presynaptic partners. We thus investigated this possibility in a retinal circuit in which GABA is transiently expressed during synaptogenesis by a subset of interneurons that are postsynaptic to photoreceptors.

In the outer retina of vertebrates, horizontal cell and bipolar cell dendrites are contacted by cone photoreceptors, forming synaptic 'triads' that are stereotypically arranged in a single lamina, the outer plexiform layer (OPL) [8]. Horizontal cells receive glutamatergic synaptic input from cone photoreceptors [9] and modulate photoreceptor transmission through feedback mechanisms $[10,11]$. Mammalian cone terminals express $\mathrm{GABA}_{\mathrm{A}}$ receptors $[12,13]$ but whether activation of 
these receptors shapes visual responses in the mature retina is still debated [14]. This uncertainty is partially due to species variability in GABA expression by adult horizontal cells [15]. Moreover, when GABA-imunoreactivity is detected, not all horizontal cells are GABAergic across the entire retina [16]. However, horizontal cells consistently express GABA during neonatal development across mammals [17], raising the possibility that outer retinal development may be influenced by GABA.

Rodent and rabbit horizontal cells express GABA and its synthetic enzyme glutamic acid decarboxylase (GAD) during a narrow window of postnatal development, but not at maturity [18-23]. These interneurons also possess a mechanism for GABA release. VGAT, the vesicular inhibitory amino acid transporter, is expressed in the dendritic and axonal processes of horizontal cells, and it is present in the outer retina as early as birth [24-26]. In rabbit cone photoreceptor terminals, the expression of $\mathrm{GABA}_{\mathrm{A}}$ receptors is transient, coincident with the period of GABA synthesis by horizontal cells [27]. Correspondingly, in vitro application of GABA results in calcium influx in neonatal but not adult cone terminals [28]. In vitro treatment of rabbit retinal explants with $\mathrm{GABA}_{\mathrm{A}}$ receptor antagonists resulted in fewer cones [29], implicating a potential role for GABA in shaping cone photoreceptor development in vivo. Furthermore, because mouse horizontal cells themselves express functional $\mathrm{GABA}_{\mathrm{A}}$ receptors [30], it is possible that perturbation of GABA synthesis leads to abnormal development of these interneurons. Additionally, because GABA is expressed by horizontal cells during the period when bipolar cell dendrites develop and invaginate into cone pedicles and bipolar cell dendrites have $\mathrm{GABA}_{\mathrm{A}}$ receptors $[8,31,32]$, it is possible that bipolarphotoreceptor synapses may be altered in the absence of GABA in the outer retina. We thus employed a genetic strategy to selectively block GABA synthesis in vivo in the mouse retina and then addressed whether synaptic development between horizontal cells, cone photoreceptors, and bipolar cells is altered.

\section{Results}

Developing mouse horizontal cells transiently express a single isoform of GAD

By using antibodies that distinguish GAD65 and GAD67, we determined which GAD isoform is transiently expressed by horizontal cells in the neonatal mouse retina [18]. We identified horizontal cells throughout development using the G42 transgenic mouse line in which these cells, and amacrine cells, express green fluorescent protein (GFP) [33,34]. At postnatal day 3 (P3) GAD67 expression was evident in both horizontal cells and amacrine cells (Figure 1). This pattern persisted at P7, but by P10, GAD67 expression was diminished in horizontal cells, although expression remained high in amacrine cells. Horizontal cells lacked GAD65 at all ages studied (Figure 2). In contrast, weak
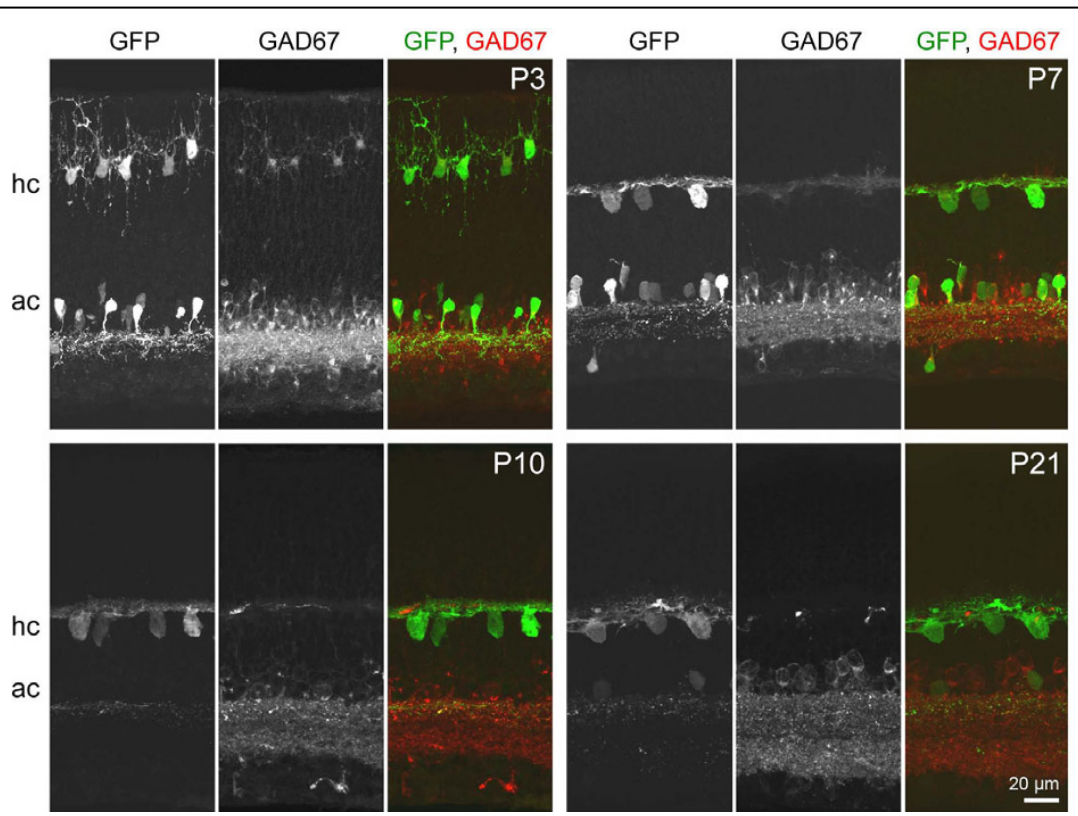

Figure 1 Horizontal cells transiently express GAD67 during early postnatal development. Retinal cross-sections from the G42 mouse in which horizontal cells (hc) and amacrine cells (ac) expressing GFP were immunolabeled for GAD67 during early postnatal development (P3 to P10) and at structural maturity (P21). 


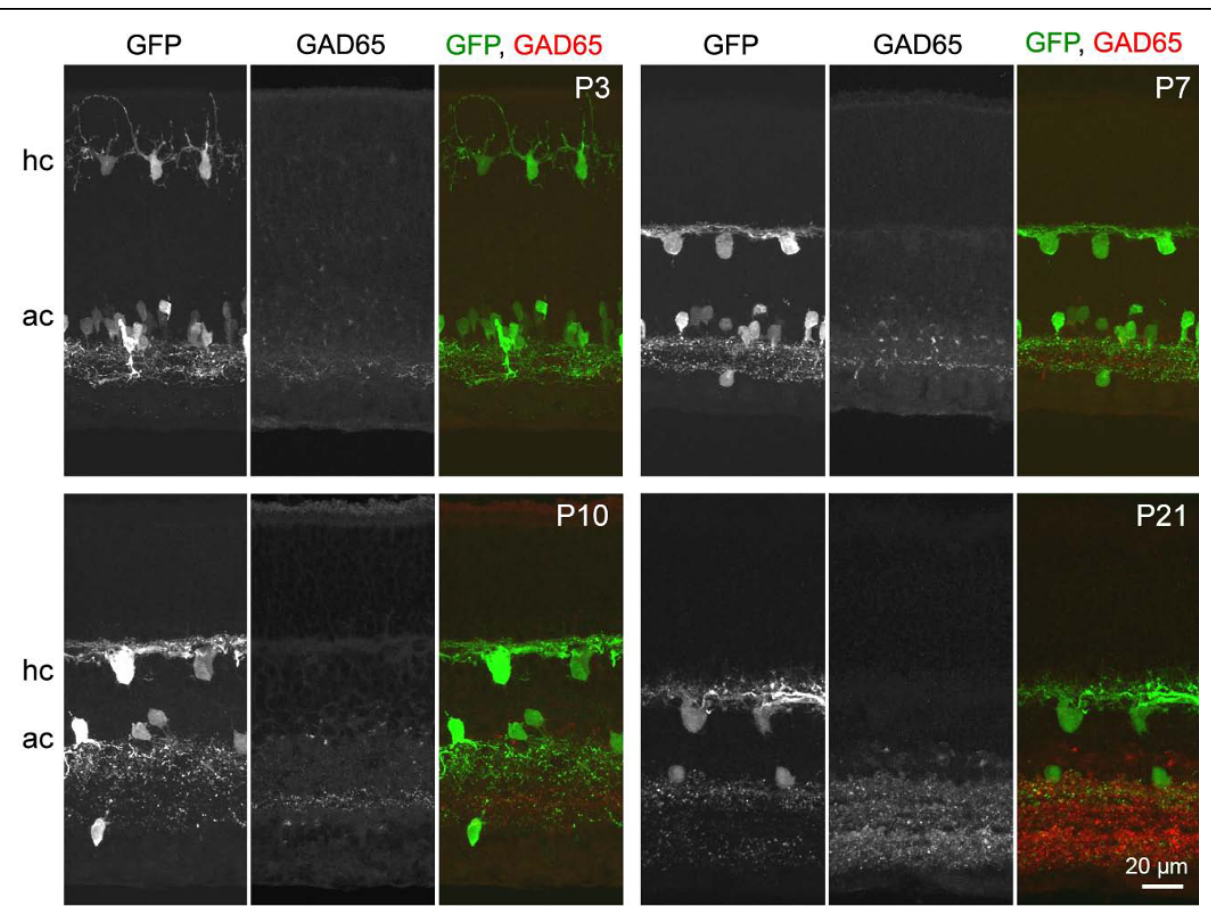

Figure 2 Horizontal cells do not express GAD65 at any stage of postnatal development. Retinal cross-sections from neonatal G42 mice immunolabeled for GAD65. hc, horizontal cells; ac, amacrine cells.

GAD65 staining of amacrine cells was present at P3 and increased in intensity by P21. Horizontal cells in the mouse retina thus transiently express a single isoform of the GABA synthetic enzyme, GAD67, which is downregulated prior to eye-opening (around P14).

\section{GABA synthesis is abolished in Cre-expressing regions of} the neonatal $\alpha$ Pax6-Cre:Gad $1^{\text {lox/lox }}$ retina

To prevent GABA expression in the horizontal cells, we selectively inactivated both alleles of Gad1, the gene encoding GAD67 [35], in these cells. Because Gad1 knockout mice die at birth [36,37], we utilized a conditional Gad1 knockout line (Gad1 ${ }^{l o x / l o x}$ ) [5] to obtain retina-specific Gad1 excision after crossing with the $\alpha$ Pax6-Cre transgenic line [38]. Cre activity in retinal progenitor cells of $\alpha$ Pax6-Cre mice is present by embryonic day 10.5 [38], prior to horizontal cell differentiation [39]. Thus, this Cre-expressing line is ideal for eliminating GABA synthesis from the outset of horizontal cell development. Offspring of the $\alpha$ Pax6-Cre: Gad1 $1^{l o x / l o x}$ cross will be referred to as mutant mice.

Because Cre-recombinase is not expressed within a dorsal-ventral wedge in the mutant mouse, we limited our analysis to regions of the retina where Cre-recombination is expected to occur (that is, nasal-temporal periphery). In these regions, loss of GAD67 expression was identified in two ways. First, Cre-expressing regions were marked by the presence of GFP expression because the $\alpha$ Pax6-Cre construct contains an IRES-GFP reporter cassette [38]. GFP expression in the mutant retina was apparent from birth through juvenile stages in neurons with a spatial organization consistent with that of amacrine cells (Figure 3a). GFP expression in amacrine cells could thus be used as a reporter of Cre activity within that field of view. Second, loss of GAD67 expression was directly confirmed by immunostaining for GAD67 (Figure 3b, c). Figure 3d demonstrates that a lack of GAD67 is accompanied by a loss of GABA. We did not observe expression of GAD65 in horizontal cells in any region of the mutant retina at the neonatal ages examined (data not shown).

\section{Lamination at the outer plexiform layer is not grossly disrupted in Gad1 mutant mice}

To assess the potential role for transient GABA synthesis by horizontal cells in the overall developmental organization of the outer retina, we examined the lamination of the dendrites of horizontal cells and the axon terminals of the photoreceptors. Horizontal cells undergo a transformation from a radial to a lateral morphology during early postnatal development, and their adult-like dendritic lamination is first apparent at around P5 $[18,34]$. This progression was not delayed in the mutant retina, compared to littermate controls $\left(\right.$ Gad1 $\left.1^{l o x / l o x}\right)$. By P5, horizontal cells in both control and mutant retinas had assumed a laminar morphology 


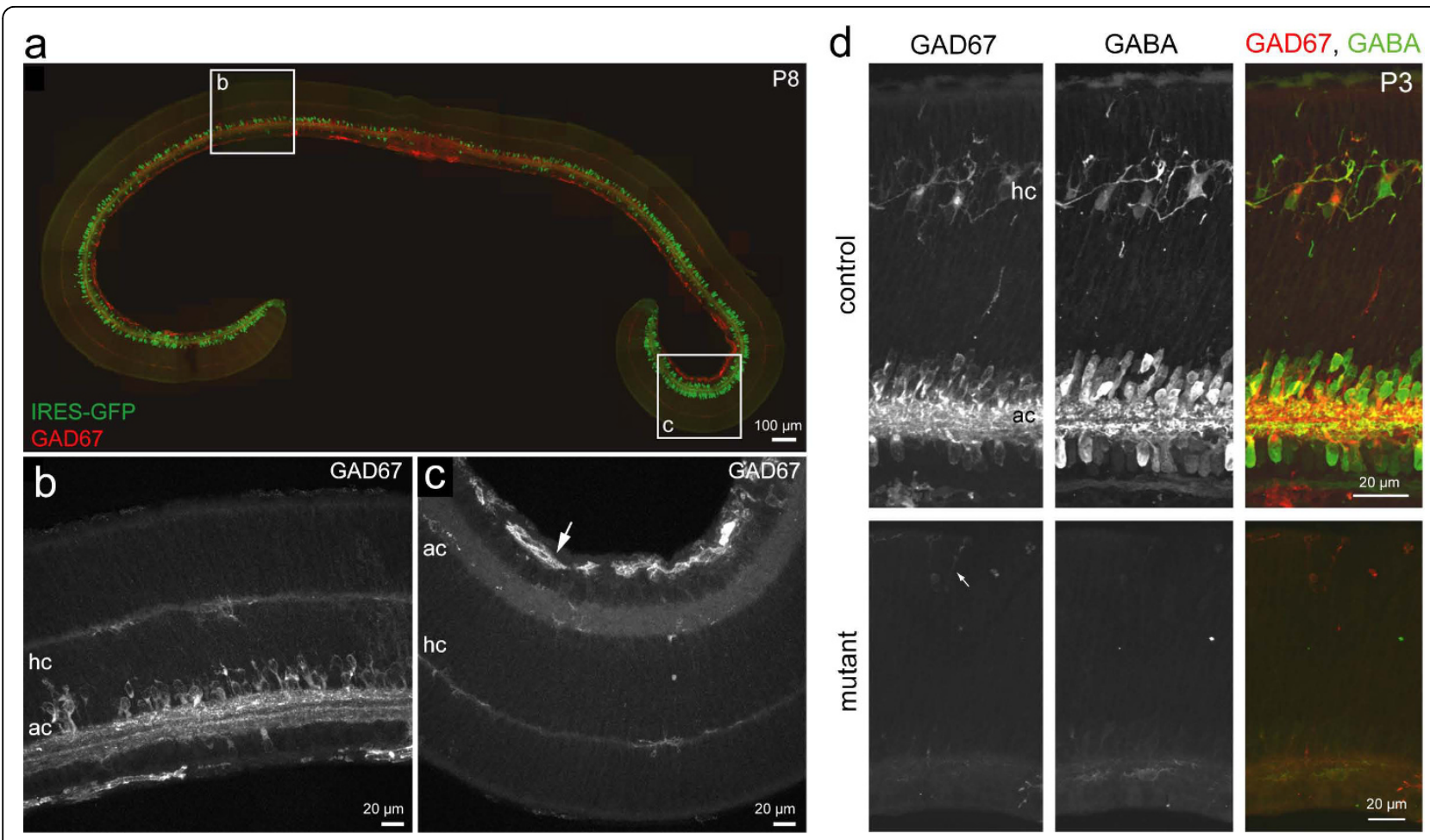

Figure 3 Pattern of GAD67 expression in $\alpha$ Pax6-Cre:Gad $1^{\text {lox/lox }}$ (mutant) retina. (a) The spatial distribution of Cre recombinase expression across the retina parallels the pattern of GFP expression in amacrine cells. Cre expression is present in all cells of the embryonic retina, but several days after birth becomes restricted to subpopulations of amacrine cells [63]. At P8, GFP is expressed by relatively few cells in central retina (box, b) and a larger number of amacrine cells in the peripheral retina (box, c). Staining for GAD67 follows an inverse pattern in this mutant retina. (b) Numerous GAD67-immunopositive amacrine cells near the center of the mutant retina. hc, horizontal cells; ac, amacrine cells. (c) GAD67 immunoreactivity is largely absent in the retinal periphery of the mutant retina. Immunofluorescence in this image (arrow) marks blood vessels. There is no GAD67 immunoreactivity at retinal depths where amacrine cells (ac) and horizontal cells (hc) are located. (d) In the wild-type region of a P3 mutant retina, GAD67-immunopositive horizontal cells (hc) also contain GABA. In knockout regions of this retina, GAD67 and GABA immunolabeling are absent. Arrow (mutant) indicates immunoreactivity in some blood vessels.

(Figure 4a) that is maintained at maturity (not shown). Cone photoreceptors also did not exhibit any gross lamination deficits in the mutant retina. When P5 cone axonal terminals were identified with vesicular glutamate transporter 1 (vGlut1) immunolabeling [40], they were appropriately targeted to the OPL in the mutant retina (Figure $4 \mathrm{~b}$ ). In addition, the targeting and lamination of bipolar cell dendrites to the OPL was not disrupted in the absence of GABA. At P10, the dendrites of protein kinase $\mathrm{C}$ (PKC)-positive rod bipolar cells and calcium binding protein 5 (CaBP5)-positive cone bipolar cells ramified in the OPL in both mutant and control retinas (Figure 5). Thus, in contrast to previous reports $[29,41]$, OPL lamination proceeded normally in the absence of GABA synthesis by horizontal cells.

Density and distribution of horizontal cells and cones are unaffected in the Gad1 mutant retina

Although transient GABA expression in horizontal cells does not affect the lamination of the OPL, it remained possible that trophic actions of GABA could influence other organizational aspects of the outer retina, such as cell density and spatial distributions of the somata of cones and horizontal cells. The populations of horizontal cells and cones were thus immunolabeled using anticalbindin and anti-cone-arrestin, respectively (Figure 6a, b). Quantitative analysis showed that the densities of both horizontal cells (Figure 6c) and cones (Figure 6d) were unaltered in the mutant retina.

We also determined whether the mosaic arrangement of the cell bodies of horizontal cells and the average distance between cone photoreceptors were altered in knockout regions of the mutantretina. To do so, we obtained the density recovery profile for each cell population and calculated the effective radius. The effective radius quantifies the extent of the region of decreased probability of encountering nearby somata of the same cell type and is therefore a measure for the regularity of cell body distribution $[34,42]$. Neither the effective radii of the horizontal cell population (Figure 6e) nor that of the cone population (Figure $6 \mathrm{f}$ ) was statistically different between mutant and control retinas. 


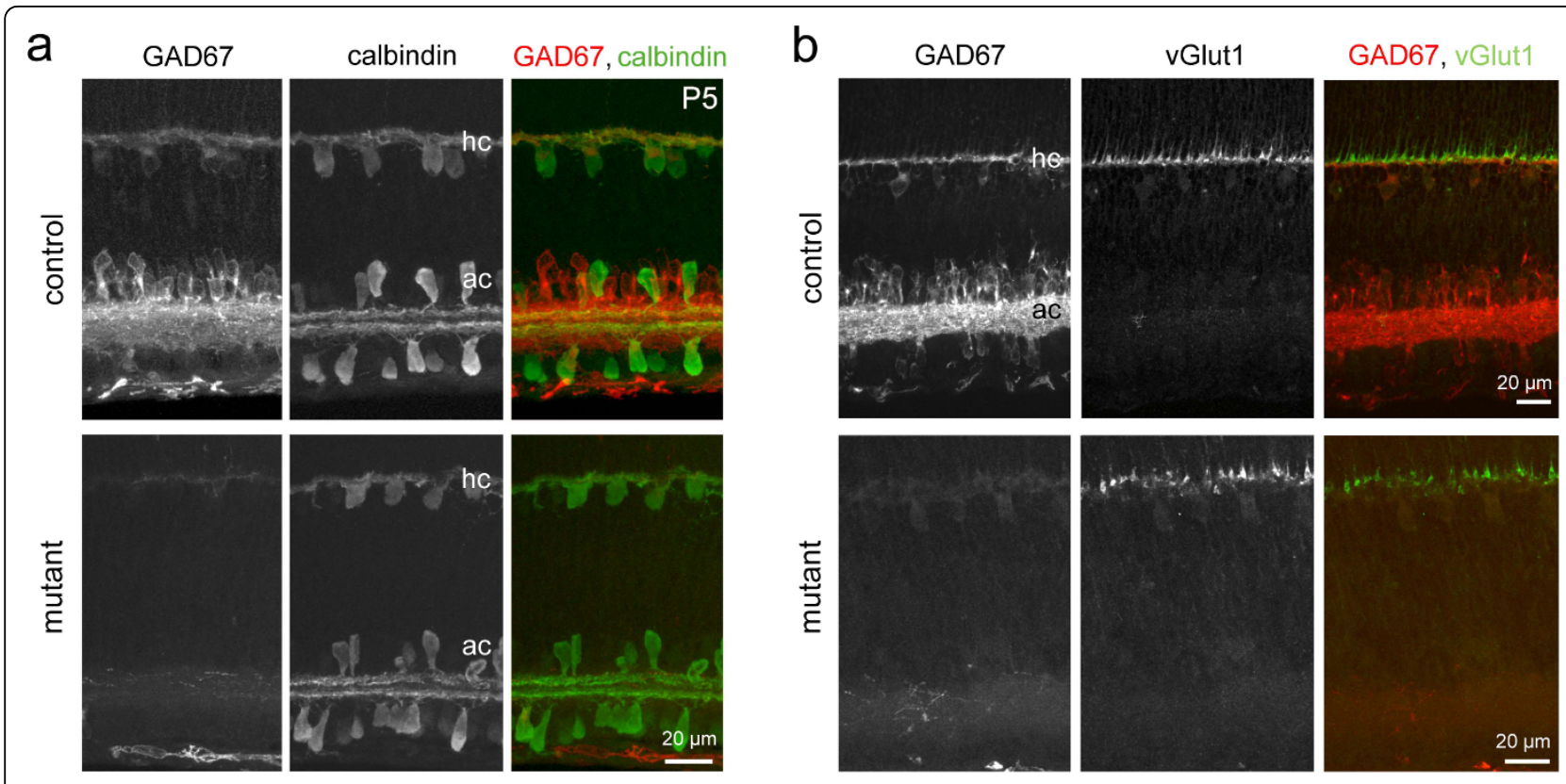

Figure 4 Horizontal cell and photoreceptor lamination are not grossly disrupted in the absence of GABA in the outer retina. (a) Horizontal cells from a P5 mutant retina immunolabeled for calbindin. In both littermate control and mutant retinas, the processes of these cells are stratified within the outer retina. (b) Photoreceptor terminals in a P5 mutant retina immunostained for vesicular glutamate transporter 1 (vGluT1). The terminals are stratified in both littermate control and mutant retinas. The slight irregularity of the mutant vGlut1 lamination is not unusual at this age and can be observed in the wild-type retina as well. hc, horizontal cells; ac, amacrine cells.

Horizontal cell dendritic terminal cluster and cone pedicle areas are increased in Gad1 mutant retina

We quantified the number of dendritic terminal clusters formed by individual horizontal cells. Varicosities within these terminal clusters have been shown previously to invaginate cone pedicles and thus represent postsynaptic sites on the horizontal cell dendrites [43]. To visualize the dendritic terminal clusters of individual horizontal cells, we intracellularly dye-filled these cells in live retina. Figure 7a shows examples of the dendritic arbors of dye-filled horizontal cells in mutant and littermate control retinas at P10, when GAD67 expression is normally just down-regulated in the horizontal cells. The average dendritic field sizes of the horizontal cells in mutant $\left(4,500 \pm 282 \mu \mathrm{m}^{2}, \mathrm{n}=30\right.$ cells) retinas were similar $(P=0.644)$ to that of controls $\left(4,760 \pm 512 \mu \mathrm{m}^{2}, \mathrm{n}=25\right.$ cells $)$. Moreover, there was no difference between the densities of terminal clusters formed by horizontal cell dendrites (number of clusters per dendritic field area) in the mutant and control (Figure 7b). Because cone density is unchanged in the mutant retina, this observation suggests that horizontal cells in the mutant mice are likely to contact the same average number of cones as in control retinas. Comparison of the average sizes of individual terminal clusters, however, revealed a statistically significant increase $(P<0.001)$ in this measure in mutant mice (Figure $7 \mathrm{c}$ ). The mean areas of the clusters were
$5.65 \pm 0.32 \mu \mathrm{m}^{2}(\mathrm{n}=14$ cells) for control and $8.90 \pm$ $0.51 \mu \mathrm{m}^{2}$ ( $\mathrm{n}=17$ cells) for mutant retinas.

We then wondered whether the increase in horizontal cell dendritic cluster size was paralleled by an increase in cone pedicle sizes. Individual cone pedicle areas were thus measured in cone-arrestin labeled retinas (see Materials and methods). Figure $7 d$ shows the region of the cone pedicles (highlighted in color) that represent the pedicle area. Filopodia (arrows) extending from the cone pedicles were not included in such measurements. Although there is a broad distribution of pedicle areas across retinas and even within a single field of view, the mean area was significantly increased $(P<0.001)$ in the mutant retinas $\left(17.15 \pm 0.46 \mu \mathrm{m}^{2}, \mathrm{n}=154\right.$ pedicles, $\mathrm{n}=$ 4 animals) compared to control $\left(15.20 \pm 0.38 \mu \mathrm{m}^{2}, \mathrm{n}=\right.$ 196 pedicles, $\mathrm{n}=5$ animals) retinas (Figure $7 \mathrm{e}$ ). Thus, horizontal cell dendritic clusters and cone pedicles are, on average, larger in mutant mice.

\section{Outer retinal synapse components in the Gad1 mutant retina appear normal}

To investigate whether the increase in horizontal cell and photoreceptor terminal sizes in the mutant retina reflect changes in synapse structure, mutant and control littermates were immunostained for cone-arrestin and C-terminal binding protein 2 (CtBP2) to co-label cone pedicles and synaptic ribbons, respectively. Figure $8 \mathrm{a}$ shows that ribbon-like structures were readily found 


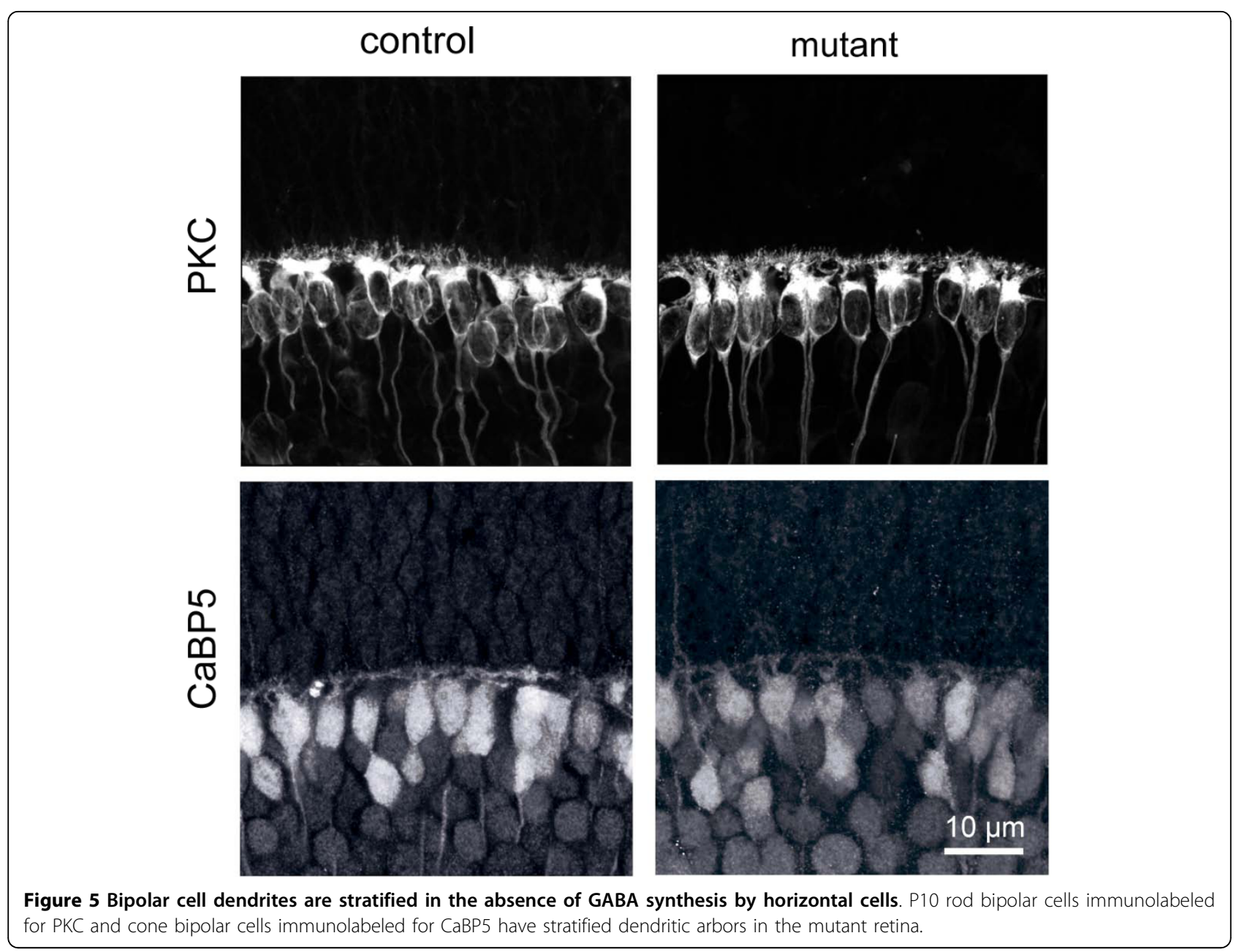

within cone pedicles in both the mutant retina and littermate controls. To obtain a higher resolution image of the ribbon synapses formed by photoreceptors onto horizontal cells, electron microscopy was carried out on mutant and control retinas at P15, when ribbons are readily identified. Both cones and rods made classic triad ribbon synapses with horizontal cells and bipolar cells (Figure 8b), suggesting that lack of GABA synthesis in horizontal cells during the period of photoreceptor synaptogenesis does not affect the fine structure of this synapse.

However, it remained possible that glutamate receptor distributions on bipolar cell dendrites that contact cone pedicles may be altered. We thus co-immunolabeled mutant and control retinas for cone-arrestin and for mGluR6, the metabotropic glutamate receptor on dendritic tips of the invaginating ON bipolar cells (Figure 9). mGluR6 receptor clusters overlaid cone pedicles of the mutant and control retinas (Figure 9a). Because it is difficult to count individual receptor clusters confidently due to the resolution of light microscopy, we obtained an estimate of receptor distribution by quantifying the total area occupied by mGluR6 receptor clusters within each cone pedicle (see Materials and methods). Plots of the absolute areas (Figure 9b) for pedicles in the mutant and control retinas demonstrate that, in general, larger pedicles have greater total receptor areas. The average total mGluR6 area within a cone pedicle for wild-type retina was $5.58 \pm 0.29 \mu \mathrm{m}^{2}$ ( $\mathrm{n}=40$ pedicles, 2 animals) and for the mutant, $6.59 \pm 0.23 \mu \mathrm{m}^{2}$ ( $\mathrm{n}=48$ pedicles, 2 animals $)$ $(P<0.016)$. We normalized for cone pedicle size by calculating the percentage of pedicle area occupied by mGluR6 receptor clusters, and found that there was a small, although significant, increase in this measure in the mutant retina $(29.00 \pm 0.64 \%)$, compared to controls $(25.90 \pm 0.74 \%)$ (Figure 9c).

\section{Discussion}

GABAergic regulation of neuronal differentiation

In past studies, treatment with GABA receptor antagonists disrupted the migration of cortical pyramidal cells, cortical interneurons, and hippocampal neurons [44,45]. 


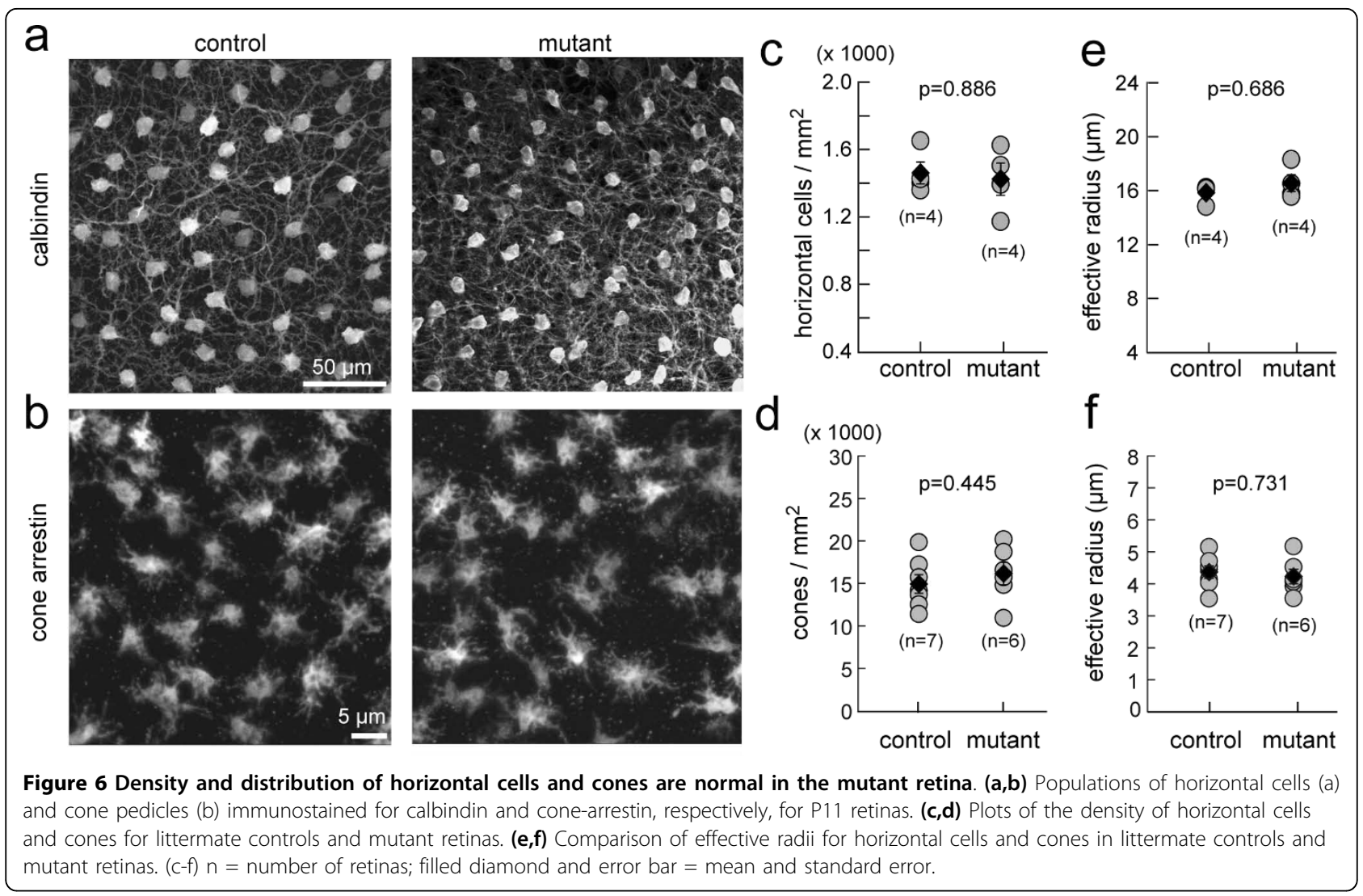

This developmental influence of GABA has been attributed to its depolarizing effect on immature neurons. Prior to expression of the $\mathrm{K}-\mathrm{Cl}$ cotransporter (KCC2), the $\mathrm{Na}-\mathrm{K}-\mathrm{Cl}$ cotransporter (NKCC) accumulates chloride ions, resulting in membrane depolarization following the activation of $\mathrm{GABA}_{\mathrm{A}}$ receptors. Depolarization activates voltage-gated calcium channels and consequently has the potential to activate numerous calcium-dependent signaling cascades. GABA-evoked depolarization has been shown to regulate the exit of neural progenitors from the cell cycle, and GABA may also influence the survival of differentiated neurons (reviewed in [2]). In the rat retina, $\mathrm{KCC} 2$ is not expressed by horizontal cells and bipolar cell dendrites until P7, well after the initial stages of OPL assembly, and it is not detected at all in photoreceptor terminals [46]. This relatively late onset of KCC2 expression and the finding that GABA application causes calcium influx into cone terminals in rabbit neonatal retinal explants [28] led to the hypothesis that GABA may exert a trophic role during the early development of the outer retina. Indeed, the number of cones in the neonatal rabbit retina is reduced following pharmacological blockade of $\mathrm{GABA}_{\mathrm{A}}$ receptors in the retina maintained in culture over several days $[29,47]$. In contrast to these previous studies, we did not find any migratory defects in the mutant retinas; horizontal cells attained an appropriate laminar position in the outer retina in the mutant retina. Moreover, the lack of GABA synthesis in the horizontal cells in the mutant retina did not affect the density of horizontal cells or cone photoreceptors.

GABA has also been shown to have a neuritogenic effect. For example, treatment with GABA increases neurite number and morphological complexity, whereas application of GABA receptor antagonists or loss of functional $\mathrm{GABA}_{\mathrm{A}}$ receptors results in simplification of neurite branching $[4,48-50]$. We found that the dendrites of horizontal cells as well as the axonal terminals of the cone photoreceptors were, however, appropriately targeted and stratified in the outer retina. Overall, the dendritic morphology of horizontal cells in the mutant retina also resembled those in the wild-type retina, and the dendrites occupied territories of similar size. However, there were morphological changes at the dendritic terminals of the horizontal cells. Horizontal cells in the mutant retina possessed larger clusters of postsynaptic varicosities, in contrast to the smaller axonal boutons found in cortical interneurons lacking GAD67 [5].

Our findings differ from observations made following intraocular injections of kainic acid that ablated horizontal cells as well as findings following the incubation of neonatal rabbit retinal explants with $\mathrm{GABA}_{\mathrm{A}}$ receptor 


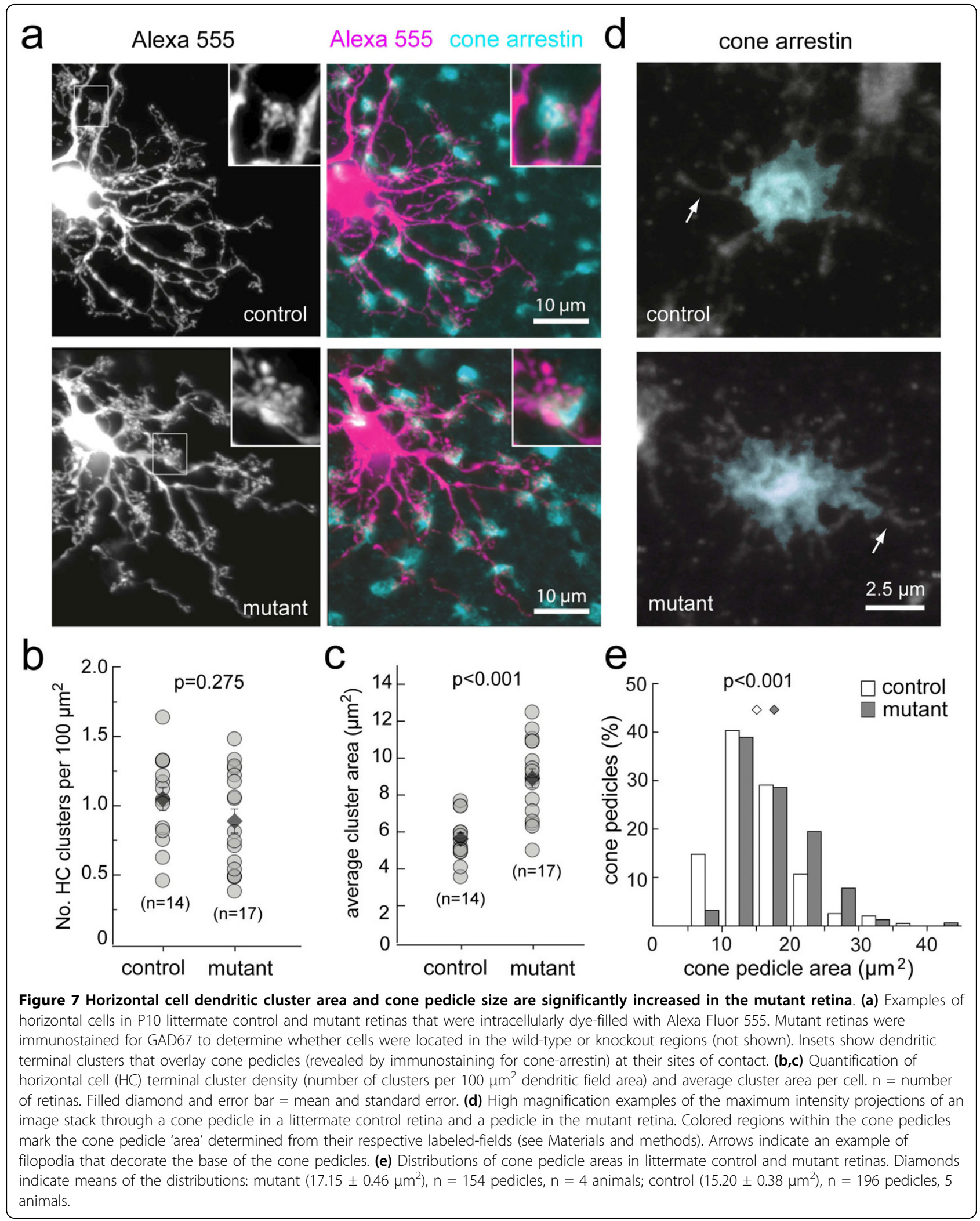




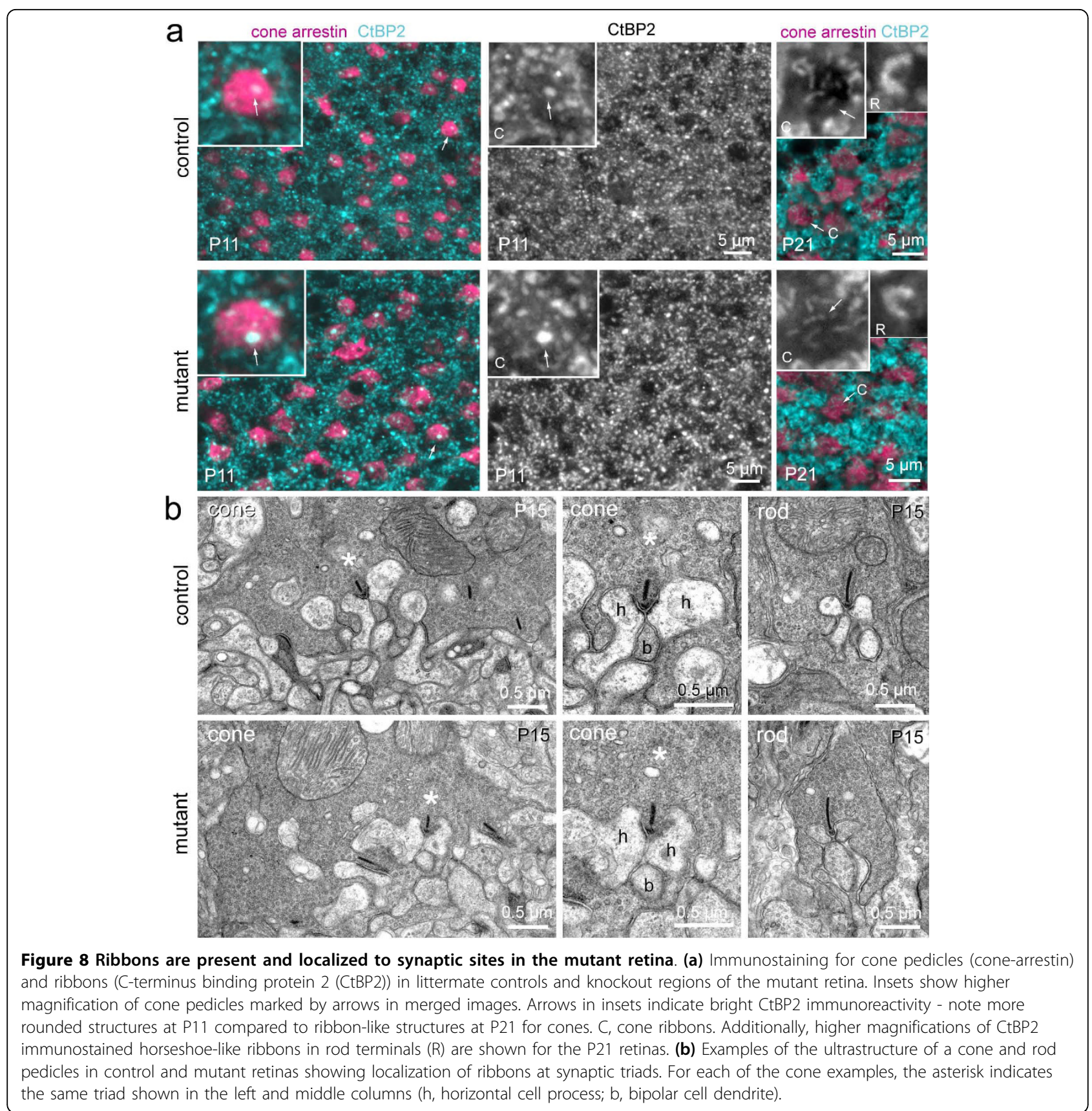

antagonists $[29,41,47]$. In these earlier studies, cone terminals were rarely observed in the OPL, and this synaptic plexus was severely perturbed. The lack of gross abnormalities in the OPL of the mutant retina we examined here is, however, in accord with studies of full GAD67 knockout animals. No large-scale defects were apparent in embryonic and P0 brains of GAD67 knockout animals [36], and organotypic cultures of hippocampus and cerebellum from these animals developed normally [51]. Similarly, the brains of mice deficient for both GAD65 and GAD67 lack major structural abnormalities [52], and retinal lamination is normal in a mutant that lacks Gad2 completely and possesses a single copy of Gad1 [53]. However, unlike these studies, restricting the loss of GAD67 expression to the retina enabled us to examine circuits that are assembled well after birth, and in the background of a complete knockout of Gad1.

One possible explanation for the different outcomes of our study and previous work on the rabbit retina is provided by Owens and Kriegstein [1], who suggested that in germline mutants, alternative pathways may 


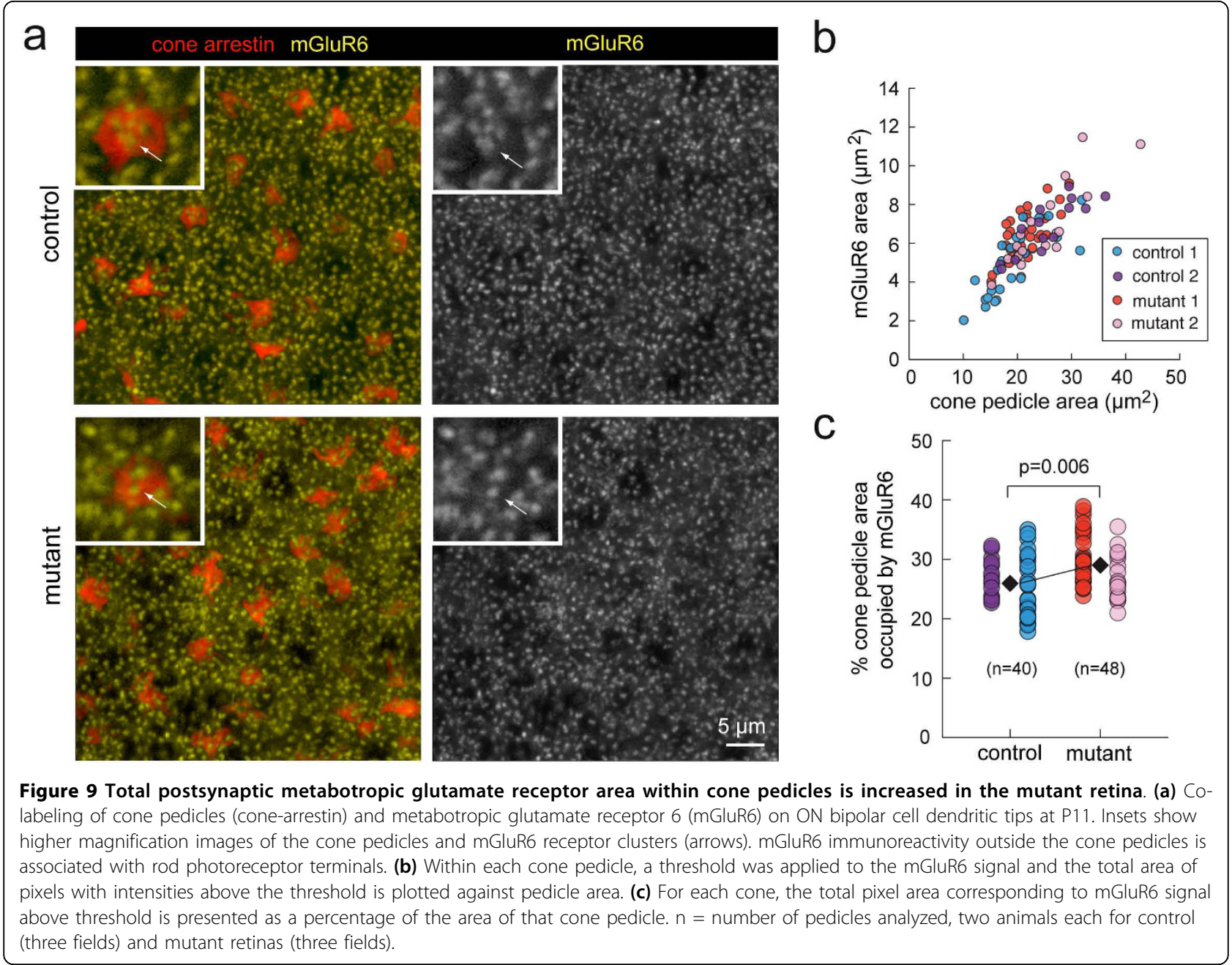

compensate for the absence of GABA synthesis and preserve normal development. They proposed taurine signaling as a candidate mechanism. This cysteine derivative is present in high levels in the developing nervous system and can activate both glycine and $\mathrm{GABA}_{\mathrm{A}}$ receptors $[54,55]$. In the rat retina, taurine is present at least transiently in all neuronal types [56]. Moreover, taurine acting on glycine receptors on retinal progenitor cells increases the production of rod photoreceptors [57]. Thus, it remains possible that in the mutant retina, taurine-mediated signaling may have compensated for the absence of GABA production in horizontal cells. Such compensatory mechanisms may not be present in retinal explants treated with $\mathrm{GABA}_{\mathrm{A}}$ receptor antagonists. Regardless of whether there might be compensation by other signaling pathways in the mutant mice, our current findings suggest that structural assembly of the OPL does not critically depend on the expression of GABA in horizontal cells. It remains to be tested whether loss of horizontal cells altogether would evoke large structural changes in the outer retina.

\section{Influence of GABA on synapse development}

There is increasing evidence to support a role for GABA in synapse development in the central nervous system. Stellate interneurons in mice lacking the alpha-1 subunit of the $\mathrm{GABA}_{\mathrm{A}}$ receptor form synapses with their targets the Purkinje cells, but the early connections are misrouted with maturation to innervate dendritic spines [58]. Thus, GABAergic transmission could help direct targeting of GABAergic axons to appropriate postsynaptic sites. More recently, a developmental role for GABA in synapse development was highlighted by findings in the visual cortex. Conditional knockout of GAD67 in basket interneurons led to sparser innervation of pyramidal neurons as well as the formation of fewer and smaller axonal terminal perisomatic boutons [5]. In these cases, both development and maturation of the 
presynaptic terminal of the GABAergic neuron appears perturbed.

Compared to other central nervous system circuits, the horizontal cell-cone photoreceptor synapse is unusual in its arrangement. Here, the GABAergic interneuron, the horizontal cell, is postsynaptic to the cone axon terminal that bears $\mathrm{GABA}_{\mathrm{A}}$ receptors. We found that knockout of GABA synthesis in horizontal cells did not alter the specialized pre- and postsynaptic triad organization of the photoreceptor, horizontal, and bipolar cell synapse. Presynaptic ribbons were localized appropriately opposite postsynaptic processes. However, we did find that the dendritic terminal clusters of horizontal cells that invaginate cone pedicles were, on average, larger in the mutant retina. The cones also exhibited a corresponding increase in their pedicle area. An increase, rather than decrease, in potential contact area between the dendrites of horizontal cells and the cones is unexpected given that past studies reveal a trophic role for GABA during development. It should be noted that the OPL is also innervated by GABAergic interplexiform cells [59]. However, in the mutant retina, these cells should have much reduced GABA synthesis since GAD67 expression was also significantly reduced in amacrine cells.

Whether the increase in cone pedicle and horizontal cell dendritic clusters reflects a functional change in the transmission from cone photoreceptors remains to be determined. To date, measuring cone transmission onto horizontal cells or bipolar cells in the mouse retina has not yet been performed in detail by electrophysiological methods, largely because such recordings are technically challenging. Thus, until physiological responses to light are fully documented for horizontal cells and bipolar cells in the wild-type mouse retina, it is not possible to comprehensively assay for potential changes in function in the OPL in the Gad1 mutant retina. Our current observations, however, would suggest that if present, physiological alterations in photoreceptor transmission in the mutant retina are unlikely to be severe, given the modest changes in structure we observed in the OPL.

\section{Methods}

All experiments were carried out under the guidelines of the University of Washington Institutional Animal Care and Use Committee (IACUC).

\section{Mutant mice}

Several transgenic mouse lines were used in this study. In the G42 mouse line, the Gad1 promoter drives GFP expression in horizontal cells [34]. In the Gad1 $1^{\text {lox/lox }}$ mice, exon 2 of Gad1, the gene encoding GAD67, is flanked by loxP sites [5]. To obtain a retina-specific excision of exon 2, this line was bred to the $\alpha$ Pax6-Cre line, in which the expression of Cre-recombinase is regulated by the alpha element of the Pax 6 promoter [38]. The excision of exon 2 in cells expressing Crerecombinase results in a frameshift mutation of Gad1[5].

\section{Dye-filling}

Tissue dissection and dye-filling of single horizontal cells with Alexa Fluor 555 hydrazide (Invitrogen, Carlsbad, California, USA) was performed as previously described [34]. In brief, isolated retinas were divided into four to eight pieces and incubated in Ames solution (pH 7.4; Sigma, St Louis, MO, USA) containing $10 \mu \mathrm{M}$ 4',6-diamidino-2-phenylindole (DAPI; Sigma) for 90 minutes at room temperature and then mounted on black filter paper (Millipore, Billerica, MA, USA) with the ganglion cell layer up. Intracellular injections were carried out with borosilicate glass electrodes (170 to 200 $\mathrm{M} \Omega$, P-87, Sutter Instruments, Novato, CA, USA) and filled with $5 \mathrm{mM}$ Alexa Fluor 555 hydrazide dissolved in $0.1 \mathrm{M}$ TRIS buffer. DAPI-stained horizontal cell somata were identified based on their large size and their location in the inner nuclear layer (INL) in close proximity to the OPL. After impaling the cell under a $63 \times$ waterimmersion objective (Zeiss Achroplan, 0.6 NA), Alexa Fluor 555 was delivered using a continuous current of $-1 \mathrm{nA}$. Only one horizontal cell was injected per retinal piece. After dye-filling, the pieces of retina were fixed in $4 \%$ paraformaldehyde for 20 minutes. The tissue was then washed and stored in $0.1 \mathrm{M}$ phosphate-buffered saline.

\section{Immunostaining}

Fixed retinas were sectioned (60 $\mu \mathrm{m}$ thickness) using a vibratome. Immunolabeling was performed using antibodies directed against GAD67 (mouse monoclonal anti-GAD67, 1:1,000; MAB5406, Chemicon, Billerica, MA, USA), GAD65 (rabbit anti-GAD65, 1:1,000; AB5082, Chemicon), GABA (guinea pig anti-GABA, 1:1,000; Chemicon), calbindin (rabbit anti-calbindin, 1:1,000; Swant, Bellinzona, Switzerland), cone-arrestin (rabbit anti-cone-arrestin, 1:400; gift of C Craft [60,61]), C-terminal binding protein 2 (mouse anti-CtBP2, 1:1,000; BD Biosciences, San Jose, CA, USA), CaBP5 (rabbit anti-CaBP5, 1:400; gift of $\mathrm{F}$ Haeseleer and $\mathrm{K}$ Palczewski), PKC (rabbit anti-PKC, 1:1,000; Chemicon), mGluR6 (sheep anti-mGluR6, 1:100; gift of C Morgans) and vGluT1 (rabbit anti-vGluT1, 1:1000; Chemicon). Secondary antibodies were Alexa Fluor 488, Alexa Fluor 568, and Alexa Fluor 633 conjugates (1:1,000; Invitrogen).

\section{Electron microscopy}

Retinas were fixed by immersion of the eyecup in $2 \%$ paraformaldehyde $/ 2 \%$ glutaraldehyde in $0.1 \mathrm{M}$ sodium 
cacodylate buffer, $\mathrm{pH} 7.4$ for 3 hours. The tissue was then washed in buffer and further fixed in $1 \%$ osmium tetroxide in cacodylate buffer for an hour prior to en bloc staining with uranyl acetate (1\%). Subsequently, the tissue was dehydrated in a graded ethanol series, embedded in araldite resin, sectioned and stained with lead citrate.

\section{Imaging}

Fixed tissue was imaged using an Olympus FV1000 laser scanning microscope and an Olympus $60 \times$ oil objective (1.35 NA). The z-step $(0.3 \mu \mathrm{m})$ was chosen according to the pixel size determined by the numerical aperture of the objective and the magnification. Each optical plane was averaged three to four times with a Kalman filter and the channels were acquired sequentially.

\section{Analysis and statistics}

Raw image stacks were processed using MetaMorph (Molecular Devices, Downingtown, PA, USA), Amira (Mercury Computer Systems, Chelmsford, MA, USA) and Imaris (Bitplane Scientific Software, Zurich, Switzerland). To confirm the loss of GAD67 in the region whereby horizontal cells were dye-filled, we performed GAD67 immunochemistry on the retina after dye-filling. Knockout regions could also be identified for intracellular dye-filling experiments at locations where there was a high density of amacrine cells expressing GFP (typically along a dorsal-ventral wedge).

For analysis of cell mosaic characteristics, the maximum intensity projections of cone-arrestin-labeled image stacks and calbindin-labeled horizontal cell image stacks were imported into Matlab (Mathworks, Natick, MA, USA). The density of horizontal cells and cone photoreceptors as well as the effective radius of their density recovery profile were calculated using customwritten Matlab routines (JL Morgan), as previously described [34].

To determine the dendritic field size of horizontal cells, dye-filled horizontal cells were first skeletonized in three-dimension (Imaris). Their dendritic field areas were then determined as the area of a polygon that encompassed all distal dendritic tips in the two-dimensional projection of the skeletonized arbor (Metamorph; custom-written Matlab routine by D Kerschensteiner). Dendritic terminal cluster sizes of dye-injected horizontal cells were obtained by calculating the areas within the outlines of the clusters in the maximum intensity projection of the cells (Metamorph; Matlab routine by D Kerschensteiner). Because dendritic clusters are not uniform across the dendritic field (they are smaller on the distal dendrites of horizontal cells [62]), we restricted our analysis to clusters located within the proximal half of the dendritic field.
Cone pedicle sizes and mGluR6 receptor area were obtained by using the label-field function of AMIRA. Briefly, for each image stack of cone-arrestin labeling, a threshold is set manually for each cone pedicle and only pixels representing the cone pedicle throughout the image stack are kept within a 'labeled' region. The variation in brightness of staining even within a single field of view required thresholds to be set for each cone separately. Pixels outside of the 'labeled' region were assigned a value of ' 0 ' whereas pixels within were assigned a value of ' 1 '. To isolate mGluR6 clusters within cone pedicles from those within rod spherules, the cone three-dimensional labeled-field was multiplied by the image stack of the mGluR6 channel. This step identified mGluR6 signal only within the volume of the cone pedicle. The area of each cone pedicle was represented by the area of the maximum projection of the labeled-field. This is because the cone pedicle is widest at its base where contact is made with horizontal cell and bipolar cell dendrites. The total mGluR6 area was calculated from the maximum intensity projection of the pixels within each cone terminal above a threshold manually set above the background mGluR6 immunofluorescence within that pedicle.

Wilcoxon rank-sum test (Sigma Stat; Systat Software, Chicago, IL, USA) was used to ascertain statistical significance for all measurements.

\section{Abbreviations}

GABA: gamma-amino-butyric acid; GAD: glutamic acid decarboxylase; GFP: green fluorescent protein; KCC2: K-Cl cotransporter; mGluR6: metabotropic glutamate receptor 6; OPL: outer plexiform layer; P: postnatal day; PKC: protein kinase C; vGluT1: vesicular glutamate transporter 1.

\section{Acknowledgements}

Supported by NIH grant EY14358 and EY001730 (Vision Core grant). We wish to thank Dr Richard D Palmiter for his generous gift of the Gad1 conditional knockout mouse. We thank Dr Cheryl Craft for the anti-cone-arrestin antibody, Dr Francoise Haeseleer for anti-CABP5 and Dr Catherine Morgans for anti-mGluR6. We also thank Dr Josh Morgan and Dr Daniel Kerschensteiner for their MatLab routines, and Dr Palmiter, Dr Felice Dunn and Adam Bleckert for critical reading of the manuscript.

\section{Author details}

${ }^{1}$ Department of Biological Structure, University of Washington, School of Medicine, 1959 NE Pacific St, Seattle, WA 98195, USA. ²Werner Reichardt Centre for Integrative Neuroscience (CIN), Institute for Ophthalmic Research, University of Tuebingen, Roentgenweg 11, 72076 Tuebingen, Germany. ${ }^{3}$ Department of Ophthalmology, University of Washington, School of Medicine, 1959 NE Pacific St, Seattle, WA 98195, USA.

\section{Authors' contributions}

TS, RMH and ROLW planned the study, performed the experiments, analyzed the data and prepared the manuscript. JEC performed parts of the immunolabeling studies, and EP carried out the electron microscopy.

\section{Competing interests}

The authors declare that they have no competing interests.

Received: 9 March 2010 Accepted: 18 June 2010

Published: 18 June 2010 


\section{References}

1. Owens DF, Kriegstein AR: Is there more to GABA than synaptic inhibition? Nat Rev Neurosci 2002, 3:715-727.

2. Represa A, Ben-Ari Y: Trophic actions of GABA on neuronal development. Trends Neurosci 2005, 28:278-283.

3. Bortone D, Polleux F: KCC2 expression promotes the termination of cortical interneuron migration in a voltage-sensitive calcium-dependent manner. Neuron 2009, 62:53-71.

4. Shen W, Da Silva JS, He H, Cline HT: Type A GABA-receptor-dependent synaptic transmission sculpts dendritic arbor structure in Xenopus tadpoles in vivo. J Neurosci 2009, 29:5032-5043.

5. Chattopadhyaya B, Di Cristo G, Wu CZ, Knott G, Kuhlman S, Fu Y, Palmiter RD, Huang ZJ: GAD67-mediated GABA synthesis and signaling regulate inhibitory synaptic innervation in the visual cortex. Neuron 2007, 54:889-903.

6. Kanold PO, Kim YA, GrandPre T, Shatz CJ: Co-regulation of ocular dominance plasticity and NMDA receptor subunit expression in glutamic acid decarboxylase-65 knock-out mice. J Physiol 2009, 587:2857-2867.

7. Hartveit E: Reciprocal synaptic interactions between rod bipolar cells and amacrine cells in the rat retina. J Neurophysiol 1999, 81:2923-2936.

8. Haverkamp S, Grünert U, Wässle H: The cone pedicle, a complex synapse in the retina. Neuron 2000, 27:85-95.

9. Pan F, Massey SC: Rod and cone input to horizontal cells in the rabbit retina. J Comp Neurol 2007, 500:815-831.

10. Kamermans M, Fahrenfort I, Schultz K, Janssen-Bienhold U, Sjoerdsma T, Weiler R: Hemichannel-mediated inhibition in the outer retina. Science 2001, 292:1178-1180

11. Hirasawa $H$, Kaneko $A$ : $p H$ changes in the invaginating synaptic cleft mediate feedback from horizontal cells to cone photoreceptors by modulating Ca2+ channels. J Gen Physiol 2003, 122:657-671.

12. Hughes TE, Grunert $U$, Karten HJ: GABAA receptors in the retina of the cat: an immunohistochemical study of wholemounts, sections, and dissociated cells. Vis Neurosci 1991, 6:229-238.

13. Vardi N, Masarachia $P$, Sterling P: Immunoreactivity to GABAA receptor in the outer plexiform layer of the cat retina. J Comp Neurol 1992, 320:394-397.

14. Wässle $\mathrm{H}$ : Parallel processing in the mammalian retina. Nat Rev Neurosci 2004, 5:747-757.

15. Mosinger $J \mathrm{~L}$, Yazulla S, Studholme KM: GABA-like immunoreactivity in the vertebrate retina: a species comparison. Exp Eye Res 1986, 42:631-644.

16. Grünert $U$, Wässle $H$ : GABA-like immunoreactivity in the macaque monkey retina: a light and electron microscopic study. J Comp Neurol 1990, 297:509-524

17. Osborne NN, Patel S, Beaton DW, Neuhoff $V$ : GABA neurones in retinas of different species and their postnatal development in situ and in culture in the rabbit retina. Cell Tissue Res 1986, 243:117-123.

18. Schnitzer J, Rusoff AC: Horizontal cells of the mouse retina contain glutamic acid decarboxylase-like immunoreactivity during early developmental stages. J Neurosci 1984, 4:2948-2955.

19. Messersmith EK, Redburn DA: gamma-Aminobutyric acid immunoreactivity in multiple cell types of the developing rabbit retina. Vis Neurosci 1992, 8:201-211.

20. Pow DV, Crook DK, Wong RO: Early appearance and transient expression of putative amino acid neurotransmitters and related molecules in the developing rabbit retina: an immunocytochemical study. Vis Neurosci 1994, 11:1115-1134.

21. Yamasaki EN, Barbosa VD, De Mello FG, Hokoc JN: GABAergic system in the developing mammalian retina: dual sources of GABA at early stages of postnatal development. Int J Dev Neurosci 1999, 17:201-213.

22. Haverkamp S, Wässle H: Immunocytochemical analysis of the mouse retina. J Comp Neurol 2000, 424:1-23.

23. Dkhissi O, Julien JF, Wasowicz M, Dalil-Thiney N, Nguyen-Legros J, Versaux Botteri C: Differential expression of $\mathrm{GAD}(65)$ and $\mathrm{GAD}(67)$ during the development of the rat retina. Brain Res 2001, 919:242-249.

24. Cueva JG, Haverkamp S, Reimer RJ, Edwards R, Wässle H, Brecha NC: Vesicular gamma-aminobutyric acid transporter expression in amacrine and horizontal cells. J Comp Neurol 2002, 445:227-237.

25. Jellali A, Stussi-Garaud C, Gasnier B, Rendon A, Sahel JA, Dreyfus H, Picaud S: Cellular localization of the vesicular inhibitory amino acid transporter in the mouse and human retina. J Comp Neurol 2002, 449:76-87
26. Johnson J, Tian N, Caywood MS, Reimer RJ, Edwards RH, Copenhagen DR: Vesicular neurotransmitter transporter expression in developing postnatal rodent retina: GABA and glycine precede glutamate. J Neurosci 2003, 23:518-529.

27. Mitchell CK, Huang $B$, Redburn-Johnson DA: GABA(A) receptor immunoreactivity is transiently expressed in the developing outer retina. Vis Neurosci 1999, 16:1083-1088.

28. Huang BO, Redburn DA: GABA-induced increases in [Ca2+]i in retinal neurons of postnatal rabbits. Vis Neurosci 1996, 13:441-447.

29. Huang B, Mitchell CK, Redburn-Johnson DA: GABA and GABA(A) receptor antagonists alter developing cone photoreceptor development in neonatal rabbit retina. Vis Neurosci 2000, 17:925-935.

30. Feigenspan A, Weiler R: Electrophysiological properties of mouse horizontal cell GABAA receptors. J Neurophysiol 2004, 92:2789-2801.

31. Vardi N, Sterling P: Subcellular localization of GABAA receptor on bipolar cells in macaque and human retina. Vision Res 1994, 34:1235-1246.

32. Greferath U, Grünert U, Müller F, Wässle H: Localization of GABAA receptors in the rabbit retina. Cell Tissue Res 1994, 276:295-307.

33. Chattopadhyaya B, Di Cristo G, Higashiyama H, Knott GW, Kuhlman SJ, Welker E, Huang ZJ: Experience and activity-dependent maturation of perisomatic GABAergic innervation in primary visual cortex during a postnatal critical period. I Neurosci 2004, 24:9598-9611.

34. Huckfeldt RM, Schubert T, Morgan JL, Godinho L, Di Cristo G, Huang ZJ, Wong RO: Transient neurites of retinal horizontal cells exhibit columnar tiling via homotypic interactions. Nat Neurosci 2009, 12:35-43.

35. Bu DF, Erlander MG, Hitz BC, Tillakaratne NJ, Kaufman DL, WagnerMcPherson CB, Evans GA, Tobin AJ: Two human glutamate decarboxylases, 65-kDa GAD and 67-kDa GAD, are each encoded by a single gene. Proc Natl Acad Sci USA 1992, 89:2115-2119.

36. Asada H, Kawamura Y, Maruyama K, Kume H, Ding RG, Kanbara N, Kuzume $H$, Sanbo M, Yagi T, Obata K: Cleft palate and decreased brain gamma-aminobutyric acid in mice lacking the $67-\mathrm{kDa}$ isoform of glutamic acid decarboxylase. Proc Natl Acad Sci USA 1997, 94:6496-6499.

37. Condie BG, Bain G, Gottlieb DI, Capecchi MR: Cleft palate in mice with a targeted mutation in the gamma-aminobutyric acid-producing enzyme glutamic acid decarboxylase 67. Proc Natl Acad Sci USA 1994, 94:11451-11455

38. Marquardt T, Ashery-Padan R, Andrejewski N, Scardigli R, Guillemot F, Gruss P: Pax6 is required for the multipotent state of retinal progenitor cells. Cell 2001, 105:43-55.

39. Young RW: Cell proliferation during postnatal development of the retina in the mouse. Brain Res 1985, 353:229-239.

40. Sherry DM, Wang MM, Bates J, Frishman LJ: Expression of vesicular glutamate transporter 1 in the mouse retina reveals temporal ordering in development of rod vs. cone and ON vs. OFF circuits. J Comp Neurol 2003, 465:480-498

41. Messersmith EK, Redburn DA: Kainic acid lesioning alters development of the outer plexiform layer in neonatal rabbit retina. Int J Dev Neurosci 1990, 8:447-461.

42. Rodieck RW: The density recovery profile: a method for the analysis of points in the plane applicable to retinal studies. Vis Neurosci 1991, 6:95-111.

43. Raviola E, Gilula NB: Intramembrane organization of specialized contacts in the outer plexiform layer of the retina. A freeze-fracture study in monkeys and rabbits. J Cell Biol 1975, 65:192-222.

44. Manent JB, Demarque $M$, Jorquera I, Pellegrino C, Ben-Ari $Y$, Aniksztejn L, Represa A: A noncanonical release of GABA and glutamate modulates neuronal migration. J Neurosci 2005, 25:4755-4765.

45. Heng Jl, Moonen G, Nguyen L: Neurotransmitters regulate cell migration in the telencephalon. Eur J Neurosci 2007, 26:537-546.

46. Vu TQ, Payne JA, Copenhagen DR: Localization and developmental expression patterns of the neuronal $\mathrm{K}-\mathrm{Cl}$ cotransporter (KCC2) in the rat retina. J Neurosci 2000, 20:1414-1423.

47. Messersmith EK, Redburn DA: The role of GABA during development of the outer retina in the rabbit. Neurochem Res 1993, 18:463-470.

48. Spoerri PE: Neurotrophic effects of GABA in cultures of embryonic chick brain and retina. Synapse 1988, 2:11-22

49. Barbin G, Pollard H, Gairasa JL, Ben-Ari Y: Involvement of GABAA receptors in the outgrowth of cultured hippocampal neurons. Neurosci Lett 1993, 152:150-154. 
50. Borodinsky LN, O'Leary D, Neale JH, Vicini S, Coso OA, Fiszman ML: GABAinduced neurite outgrowth of cerebellar granule cells is mediated by $\mathrm{GABA}(\mathrm{A})$ receptor activation, calcium influx and CaMKII and erk1/2 pathways. J Neurochem 2003, 84:1411-1420.

51. Ji F, Obata K: Development of the GABA system in organotypic culture of hippocampal and cerebellar slices from a $67-\mathrm{kDa}$ isoform of glutamic acid decarboxylase (GAD67)-deficient mice. Neurosci Res 1999, 33:233-237.

52. Ji F, Kanbara N, Obata K: GABA and histogenesis in fetal and neonatal mouse brain lacking both the isoforms of glutamic acid decarboxylase. Neurosci Res 1999, 33:187-194.

53. May CA, Nakamura K, Fujiyama F, Komatsu Y, Yanagawa Y: Homozygous GAD65 and heterozygous GAD67 knock-out mice reveal normal retinal development and maintenance despite reduced amounts of GABA. Acta Neuropathol (Berl) 2007, 113:101-103.

54. Lewis CA, Ahmed Z, Faber DS: A characterization of glycinergic receptors present in cultured rat medullary neurons. J Neurophysio/ 1991, 66:1291-1303

55. O'Byrne MB, Tipton KF: Taurine-induced attenuation of MPP+ neurotoxicity in vitro a possible role for the GABA(A) subclass of GABA receptors. J Neurochem 2000, 74:2087-2093.

56. Lake $\mathrm{N}$ : Taurine and GABA in the rat retina during postnatal development. Vis Neurosci 1994, 11:253-260.

57. Young $\mathrm{TL}$, Cepko CL: A role for ligand-gated ion channels in rod photoreceptor development. Neuron 2004, 41:867-879.

58. Fritschy JM, Panzanelli P, Kralic JE, Vogt KE, Sassoè-Pognetto M: Differential dependence of axo-dendritic and axo-somatic GABAergic synapses on GABAA receptors containing the alpha1 subunit in Purkinje cells. $J$ Neurosci 2006, 26:3245-3255.

59. Dedek K, Breuninger T, de Sevilla Müller LP, Maxeiner S, Schultz K, JanssenBienhold U, Willecke K, Euler T, Weiler R: A novel type of interplexiform amacrine cell in the mouse retina. Eur J Neurosci 2009, 30:217-228.

60. Zhu X, Li A, Brown B, Weiss ER, Osawa S, Craft CM: Mouse cone arrestin expression pattern: light induced translocation in cone photoreceptors. Mol Vis 2002, 8:462-471.

61. Nikonov SS, Brown BM, Davis JA, Zuniga Fl, Bragin A, Pugh EN Jr, Craft CM: Mouse cones require an arrestin for normal inactivation of phototransduction. Neuron 2008, 59:462-474.

62. Reese BE, Raven MA, Stagg SB: Afferents and homotypic neighbors regulate horizontal cell morphology, connectivity, and retinal coverage. J Neurosci 2005, 25:2167-2175.

63. Stacy RC, Demas J, Burgess RW, Sanes JR, Wong RO: Disruption and recovery of patterned retinal activity in the absence of acetylcholine. $J$ Neurosci 2005, 25:9347-9357.

doi:10.1186/1749-8104-5-15

Cite this article as: Schubert et al.: Assembly of the outer retina in the absence of GABA synthesis in horizontal cells. Neural Development 2010 5:15.

\section{Submit your next manuscript to BioMed Central and take full advantage of:}

- Convenient online submission

- Thorough peer review

- No space constraints or color figure charges

- Immediate publication on acceptance

- Inclusion in PubMed, CAS, Scopus and Google Scholar

- Research which is freely available for redistribution 